\title{
MORPHOLOGY AND GENESIS OF PEDOGENIC OOIDS IN CALCIC AND PETROCALCIC SOIL HORIZONS
}

ETHAN W. CONLEY, Beloit College

Research Advisor: Jim Rougvie

\section{INTRODUCTION}

Arid and semi-arid landscapes cover nearly a third of Earth's terrestrial environments, and support two billion people. With accelerated warming predicted for the Earth (Retallack, 2001), these landscapes must be thoroughly understood in both their current and future states. Arid soils are defined by the lack of available water for leaching, and instead often accumulate soluble salts such as calcite. Calcic and petrocalcic horizons form as secondary calcium and other carbonates accumulate in one or more parts (horizons) of the soil profile over time (Bockheim, 2014). Calcic and petrocalcic horizons provide important paleoenvironmental data through geochemical, stable isotopic, and micromorphological analysis of their CaCO3 accumulation (Machette, 1985).

\section{Calcic soil formation and evolution}

Importantly, carbonate horizons evolve over time, transitioning from sparsely indurated, friable calcic horizons into completely cemented, hard petrocalcic horizons over $10^{3}$ to $10^{6} \mathrm{yr}$ timescales. Petrocalcic horizons and paleosols (Soil Survey Staff, 2014) have long been recognized as soil and stratigraphic features although informally called caliche or calcrete in older geologic literature (Bachman and Machette, 1977). A six-stage model of calcic to petrocalcic horizon development illustrates the processes through which these soils evolve (Gile et al., 1966; Machette, 1985; Schoeneberger et al., 2012).

The rate of evolution from calcic (Stages I-III) to petrocalcic (Stages IV-VI) depends on the parent material (mineralogy and texture),geomorphic setting, and climate. But other studies demonstrate the need to adapt the horizon-centric stage model for sitespecific purposes addressing profiles with multiple (petro)calcic horizons or with dynamic climate or geomorphic histories (e.g., Zarza et al., 1992; Brock and Buck, 2009).

\section{Micromorphology}

The six stage model describes progressive morphological horizon development, but does not specifically address all micro-morphological features forming within the horizon during that evolution. Example features that are addressed by the model include pisoliths, pisoids, and laminae. Pisoliths are teardrop shaped structures that form when carbonate accumulations form pendants on the undersides of petrocalcic fragments sourced from the erosion and re-deposition of precursor calcic horizons, or other coarse fragments (Brock and Buck, 2009). Pisoids are round structures $>2 \mathrm{~mm}$ in diameter that have a varying range of internal morphologies (concentrically laminated or massive, nucleic or anucleic) (Robins et al., 2015). Pisoids are thought to form in stage VI as a result of the breaking up, transportation, and erosion of precursor, indurated matrix, nodules, or other features. Laminae are fine ( $\mathrm{mm}$ scale) layers of carbonate, clay, or other pedogenic minerals $<1 \mathrm{~cm}$ thick (Zarza et al., 1992; Brock and Buck, 2009). The most prominent laminae sets are thought to develop as horizon caps (Stage IV) when pore spaces are plugged by Stage III carbonate accumulation and infiltration is restricted (stage IV) (Brock and Buck, 2009). Vertical laminae surrounding pisoids may correlate to erosional or dissolution events (piping) which can give insight into more recent climatic events, but their timing relative to horizontal laminae is less clear. 
Importantly, ooids - a term borrowed from sedimentology - are intriguing micromorphological features that also often occur in (petro)calcic horizons, but which are not yet addressed by the six-stage model. Pedogenic ooids are concentric structures $<2$ $\mathrm{mm}$ in diameter with variable internal morphologies (Halley, 1977). In calcic horizons they occur not only in isolation, but also in groups within larger macro-morphological features such as clast pendant laminae, pisoids, and laminae (Robins et al., 2015). Sedimentological ooids generally form in shallow, near-shore waters where waves or currents rotate grains in alkaline, calcite-precipitating waters, forming spherical secondary mineral coats around the nucleus grain. This model has been recreated in different lab settings (Deelman, 1978). By contrast, several competing hypotheses exist for pedogenic ooid origins. Robins et al. (2015) suggest ooids form in Stage I-III calcic horizons via combined: (A) mineralization during the evaporation of solutions held by surface tension around grains, clasts and other fragments, (B) hydration of plastically-behaving fibrous phyllosilicates, and (C) small, repetitive rotations caused by crystallization pressures from pedogenic minerals during soil solution evaporation s (Robins et al., 2015). However, ooid occurrence has not been pervasively surveyed, and it remains possible that pedogenic ooids may also form in stage IV+ petrocalcic horizons.

This project systematically studies ooid presence and absence in stage II-VI (petro)calcic horizons to test existing hypotheses for their genesis. Understanding the timing of pedogenic ooid formation would refine models of petrocalcic horizon development and may assist paleoenvironmental reconstruction from petrocalcic horizons or paleosols.

\section{METHODS}

\section{Site selection}

Mormon Mesa, in South-Eastern Nevada, USA, is both remarkable and unique in terms of its age and soil profile characteristics. From the Miocene to the Pliocene, the tectonic basin which today hosts Mormon Mesa filled with alluvial, eolian, and lacustrine sediments of the Muddy Creek Formation
(MCF). Fluvial incision by the Virgin and Muddy Rivers (in response to Colorado River incision), plus continued Pliocene to Holocene alluvial fan sedimentation and eolian deposition formed the mesa and the Mormon Mesa soil series (Gardner, 1972). Flat Top Mesa is an isolated erosional remnant of Mormon Mesa's former extent and sits just east of the main soil geomorphic surface. Mormon Mesa makes an excellent ooid case study because its profile expresses stages II-VI, has been previously well described (Brock and Buck, 2009) and is known to exhibit pedogenic ooids in one or more horizons (Robins et al., 2015).

\section{Field description and sampling}

Three sites were chosen for soil-stratigraphic description and sampling in June, 2018, along roadcuts and the mesa's edge. Each exposure contained four main calcic or petrocalcic soil/paleosol horizons of interest $=($ Fig. 1). Ordered from bottom to top, the horizons are a stage II paleosol horizon within the upper MCF below the Mormon Mesa soil, followed, upwards in profile by: a stage III Transitional horizon (base of MM profile), Massive horizon (Stage VI), and brecciated rubble cap (Stage VI) intermixed with unconsolidated alluvium (Brock and Buck, 2009). Samples were taken from each of these horizons at three sites: Riverside (RR), Flat Top East (FTE), and Flat Top West (FTW).

Massive horizon samples were collected to capture different features including laminae, pisoliths, and pisoids, as well as several samples with no identifiable morphological features (massive matrix only). Transitional horizon samples averaging 3 $\mathrm{cm}$ in diameter were collected at random. Stage II MCF paleosol horizon, carbonate nodules were also randomly selected.

\section{Laboratory methods}

Eighteen billets were cut from the rubble layer and massive horizon for thin section preparation by Spectrum Petrographic Inc. (Vancouver, WA). Spurr low viscosity resin was used to epoxy friable transitional and MCF samples.

Thin sections were studied using optical light 


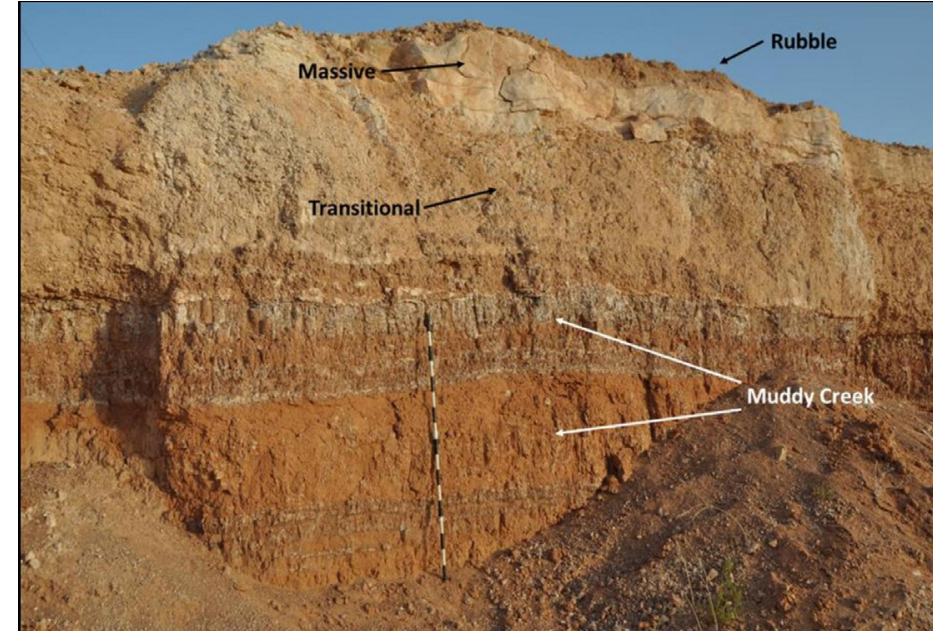

Figure 1: Mormon Mesa soil profile showing the four major horizons discussed in this study. The rubble horizon is a layer of weathered brecciated stage VI soil. The massive horizon is a stage VI petrocalcic horizon with a complex range of macro and micro-morphologic features. The transitional horizon is a moderately indurated stage III calcic horizon. The stage II MCF parent material is mixed alluvium and eolian sand. Mudstones with efflorescent crusts are also visible.

microscopy and scanning electron microscopy (SEM) at the Beloit College Geology Department. A random walk survey identified ooid locations in each slide. Each was photographed, and marked for subsequent SEM analysis.

SEM analysis employed the same billets from thin section preparation, but study was limited to massive horizon samples only due to time and logistical constraints. Billets were polished to remove saw marks and then etched in $10 \% \mathrm{HCl}$ solution for 3 seconds to enhance contrast between minerals and features. Samples were immediately transferred to deionized water for rinsing and then air-dried. After etching, billets were Au sputter coated and imaged in a JEOL JSM-5900LV SEM at $15 \mathrm{kV}$.

\section{RESULTS}

Ooids are not found in the MCF carbonate nodules. The carbonate nodules are irregular concretions; individual nodules with average diameters of 2-3 $\mathrm{cm}$ are surrounded by a sandy to silty matrix with a carbonate cement. Grains inside of the nodules lack visible grain coats and fabric is massive.

Transitional horizon samples yielded both micro and macro-morphological features including ooids and pisoliths. Ooids exhibited three generalized morphologies (Fig.2). Category one ooids have nuclei composed only of clay or a collection of secondary minerals, and have a circular grain coating (Fig.2 A) (Fig.3). Category two ooids have nuclei composed of quartz, feldspar, and/or carbonates and the outer coats are neither circular nor concentric (Fig.2 B) (Fig.4 A\&B). Instead, the grain coats conform to the nucleus's shape and fill all void space between grains (Fig.2 B). Category three ooids have nuclei composed of quartz, feldspar, and/or carbonates but the grain coats are circular and concentric (Fig.2 C\&D) (Fig.4 C-F). Category two ooids are most prevalent in the transitional horizon. At all three sites, ooids are scattered within the transitional horizon and are not concentrated within any specific area nor feature.

Ooids in the massive horizon were less morphologically diverse, but occurred in the highest concentrations of any horizon. Both category two and three ooids were seen, with category three the most abundant. Ooids appear in all massive horizon sample areas, but the highest concentrations occur in thickly laminated zones, especially in RR and FTE samples.

The brecciated and rubble layer samples are more weathered than the previous horizons with commonly observed surface dissolution of pisoids and pisoliths. Both macro and micro-morphological features including laminae, pisoids, pisoliths, and ooids are present and similar to the massive horizon. Complex laminae surround and wrap around small pisoliths as well as pisoids, and ooids $(<2 \mathrm{~mm})$ are visible within the laminae themselves. In grab samples, especially from Flat Top East, several large dissolution seams are present that contain entire sections of ooids. Grain size varies and several grains have carbonate bridges connecting the ooids in an hourglass shape.

\section{DISCUSSION}

In conjunction with previous research, these results help better illustrate the usefulness of pedogenic ooids as paleoenvironmental indicators and establish a place-holder for the timing of pedogenic ooid formation within the six stage model (Gile et al., 1966, Machette, 1985, Schoeneberger et al., 2012).

\section{Ooid morphology}


Category one ooids are interpreted as biogenic. They share similar diameters and mineralogical compositions with previously described calcite spherulites from animal dung (Canti, 1998). Another possible origin for this ooid class is development as filled root casings or deformed and enriched casts and imprints of cells from microbial mats that were present in the soil prior to the beginning of the calcification process (Gerdes et al., 1994). The structure of these grains would have started with an initial coating, but no nuclei because of their cellular structure. Over time, clays and possibly other minerals fill the void space in the center of the structure to give it an ooid appearance.

Category two ooids are interpreted as abiotic grain coats. These ooids have irregular structures (Fig. 4 $\mathrm{A} \& \mathrm{~B})$ and the grain coats consist of clay, or clay and carbonate. Some coatings do not completely encompass the grain, but rather truncate partway. Category two ooids are hypothesized to form as grain coats around a stationary nucleus with void space around it. The coatings are not rounded (Figure 2B), suggesting there was no motion forming the coat itself. Instead, the crystallizing coat filled all available voids around the central grain. This also explains why some grain coats do not completely surround

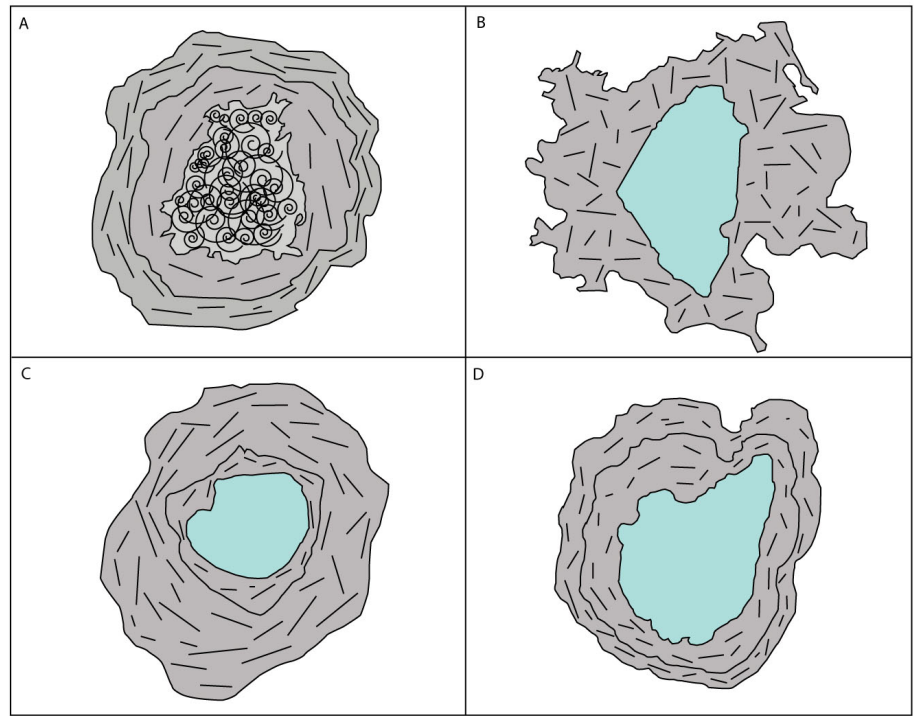

Figure 2: A) Category one ooid (clay nuclei) interpreted as forming from termite/worm frass and or other biological processes. (B) Category two ooid (grain coat growing into void space) with quartz, feldspar, or carbonate nuclei, but irregular coating. (C) Category three ooid (spherical and concentric grain coat) with quartz, feldspar, or carbonate nuclei. (D) Category three ooid, but with an irregular nuclei.

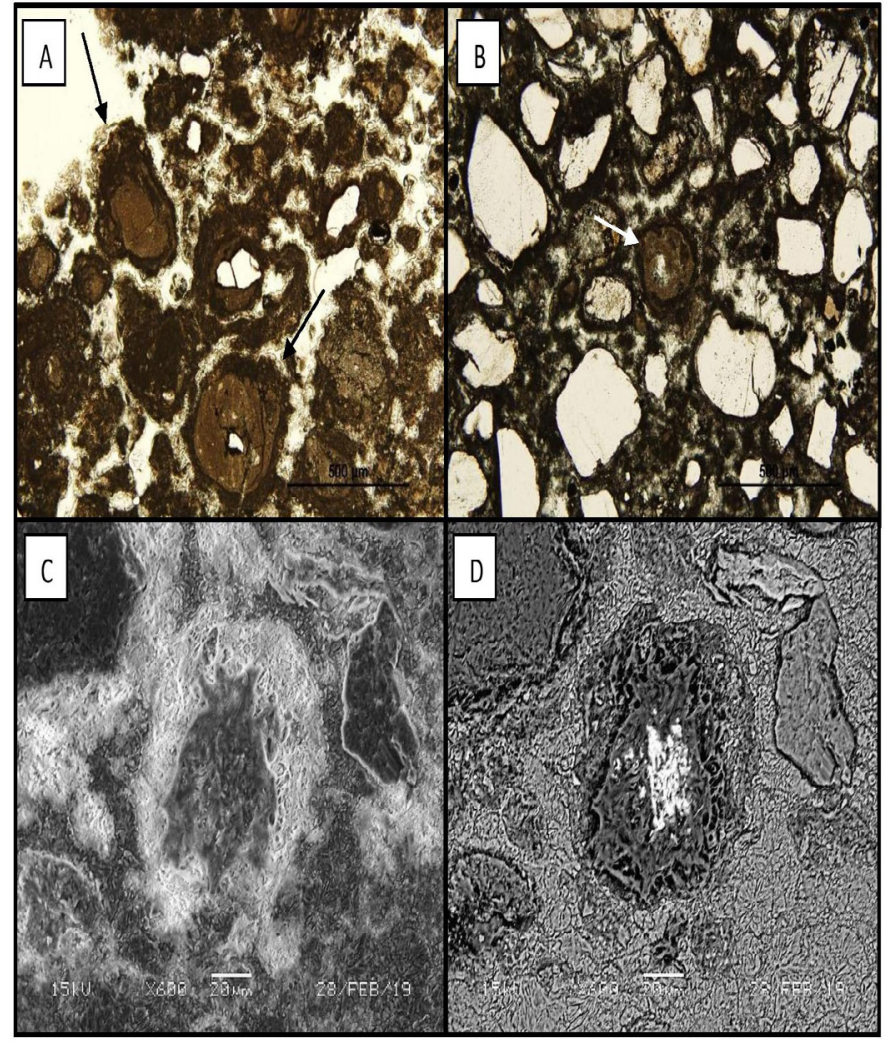

Figure 3: A) Two category one ooids. (B) Category one ooid. (C) Secondary Electron Image of a category one ooid. (D) Backscatter Electron Image of a category one ooid found in $C$.

all grains because if there was initial grain-to-grain contact, there would be no void space for a coating to crystallize into. Some grains of this category only have a thin rind around them. In areas of tightly packed grains, with little available void space, a thinner coating develops instead.

Category three ooids are most abundant in the massive horizon and have high concentrations within laminae. Laminae form due to solution flow or pooling along impermeable contacts. In these areas, movement of grains is plausible. If this motion has a high enough energy to roll, rotate, and transport these grains, even in very small, episodic movements over multiple seasons or years, then the expected coat would grow and crystallize spherically. Thus, category three ooids likely form due to the result of some sort of motion.

Category two ooids are most abundant in the transitional horizon and category three ooids are most abundant within the massive horizon. These results support hypothesized processes in which 


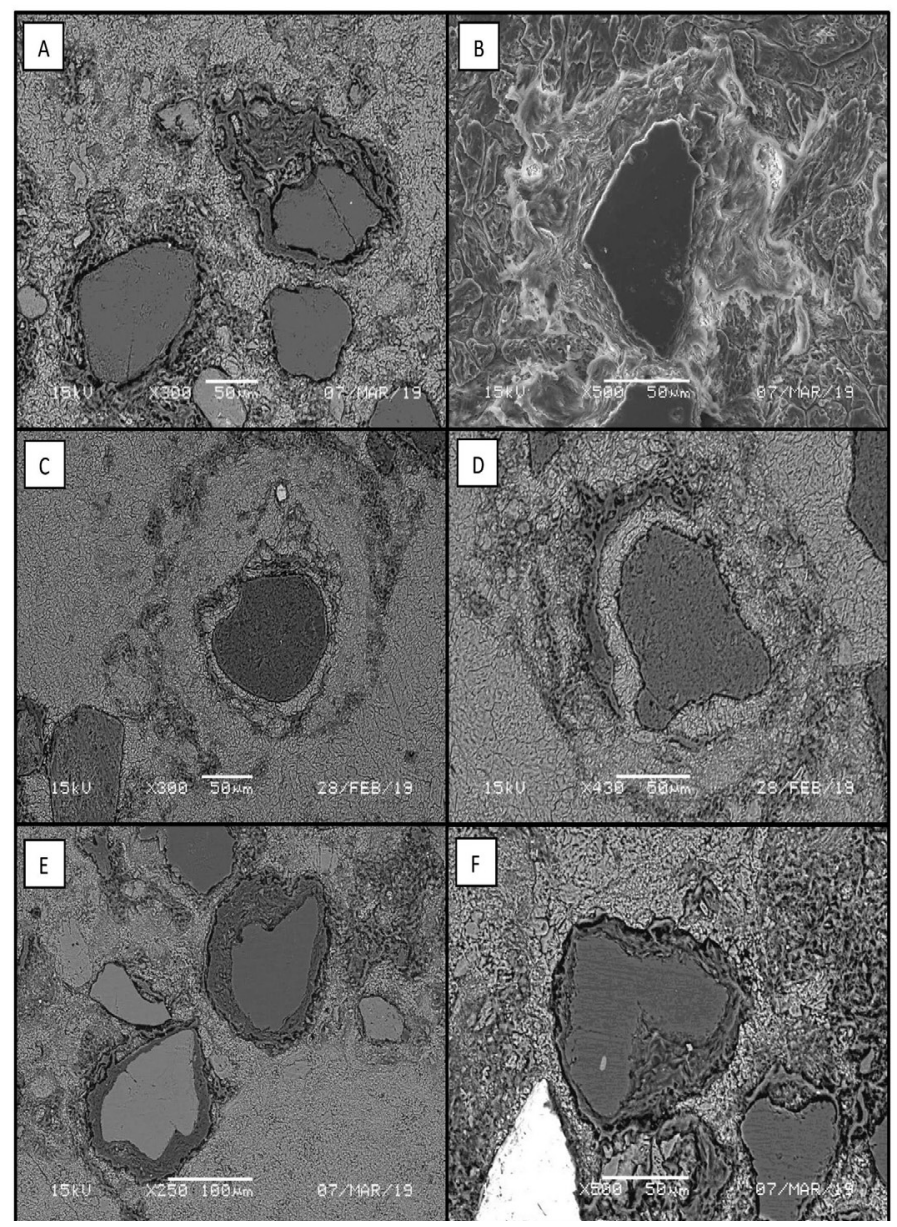

Figure 4: (A\&B) SEM images of category two ooids lacking spherical and concentric grain coats. (C\&D) SEM images of category three ooids with spherical and concentric grain coats. E\&F) SEM images of category three ooids with spherical grain coatings despite irregular nuclei shape.

these two categories of ooids form because in the less indurated transitional horizon the need for void space is satisfied. Ooids in the massive, stage VI horizon form when joints, fractures, and pipes are opened during times of profile degradation, filled by new, younger material, and then recemented. These interpretations also explain the locations of the ooids within the different horizons. Pervasive porosity in the transitional would yield more scattered assemblage of category two ooid growth (Khresat, 2001). Fluid motion in these soils follows the paths of either fractures or impermeable surfaces which would make the formation locations of category three ooids more predictable.

\section{Timing of Formation}

Category one ooid formation begins within stage I as root casings and pores develop carbonate coatings.
These calcareous coatings retain the structure of the original roots and cells, but may not finish formation until stage III (Jaillard et al., 1991).

Category two ooids begin forming in stage III. During stage II, calcification and induration is incomplete and grains, especially those within the carbonate nodules, would not yet be immobile. Confining pressure is not achievable until Stage III, when the horizon is plugged by carbonate.

Category three ooids may form independently of category two ooids as a brand-new cycle sparked by motion or laminae formation. Another possibility is that category three ooids are older more developed versions of category two ooids. Category two ooids could be plucked out of place by infilling processes and laminae formation. These ooids could then become rounded from rolling and turning (Deelman, 1978) as they grow a new coating around the previously formed irregular coating. This would explain the concentric, rounded rings (spherical coats) marking individual growth periods or events. This could also explain why some massive horizon ooids still display characteristics of category two. If those grains were never moved, then they would have never developed a new, spherical coating.

\section{CONCLUSIONS}

The only ooids observed in this study meeting traditional ooid definitions (Deelman, 1978; Prothero and Schawb, 2014) in the geologic literature are category three because of their spherical, concentric grain coats and context (Robins et al., 2015). Category three ooids do not complete their formation until late stage III to stage VI. For the six-stage model of calcic horizon formation (Gile et al., 1966; Machette, 1985; Schoeneberger et al., 2012) this implies that the other two categories begin forming as early as stage I and certainly by early stage III. Thus, with at least three plausible modes of genesis, pedogenic ooids are useful paleoenvironmental indicators which tell the story of what has, and just as importantly, what has not happened to the soil profile in different climatic cycles.

\section{ACKNOWLEDGEMENTS}


This material is based upon work supported by the Keck Geology Consortium and the National Science Foundation under Grant No. 1659322. Additional support was provided by the Pomona College Geology Department, The W.M. Keck Science Department of Claremont McKenna, Pitzer, and Scripps Colleges, and by the Beloit College Geology Department. I thank C. Robins and J. Rougvie for advising this project and fellow Team Nevada colleagues K. Crandall, I. Futterman, and P. Vorster for their enthusiasm and friendship during the project, and continued collaboration during both research and writing.

\section{REFERENCES}

Alonso-Zarza, A.M., Wright, V. P., Calvo, J. P., and Garcia del Cura, M.A., 1992. Soil-landscape and climatic relationships in the middle Miocene of the Madrid Basin. Sedimentology 39 (1):17-35.

Bachman, G.O., and M.N. Machette, 1977. Calcic soils and calcretes in the southwestern United States. U.S. Geological Survey Open File Report 77-794. U.S. Government Printing Office, Washington, DC.

Bockheim J.G., 2014. Calcic and Petrocalcic Horizons. In: Bockheim, J.G. Soil Geography of the USA. Springer Publishing

Brock, A.L. and Buck, B.J., 2009. Polygenetic development of the Mormon Mesa, NV petrocalcic horizons: Geomorphic and paleoenvironmental interpretations. Catena 77 : $65-75$.

Canti, M., 1998. Origin of calcium carbonate granules found in buried soils and Quaternary deposits. Boreas, 27 (4): 275-288.

Deelman, J. C., 1978. Experimental ooids and grapestones; carbonate aggregates and their origin. Journal of Sedimentary Petrology 48 (2): 503-512.

Gardner, L.R., 1972. Origin of the Mormon Mesa Caliche, Clark County, Nevada. Geological Society of America Bulletin 83: 143-156.
Gerdes, G., Dunajtschik-Piewak, K., Riege, H., Taher, A. G., Krumbein, W. E., \& Reineck, H. E., 1994. Structural diversity of biogenic carbonate particles in microbial mats. Sedimentology 41 (6): 1273-1294.

Gile, L.H., Peterson, F.F., Grossman, R.B., 1966. Morphological and genetic sequences of carbonate accumulation in desert soils. Soil Science 101 (5): 347-360.

Halley, R. B., 1977. Ooid fabric and fracture in the Great Salt Lake and the geologic record. Journal of Sedimentary Petrology 47(3): 1099-1120.

Jaillard, B., Guyon, A., \& Maurin, A. F., 1991. Structure and composition of calcified roots, and their identification in calcareous soils. Geoderma 50 (3): 197-210.

Khresat, S. A., 2001. Calcic horizon distribution and soil classification in selected soils of northwestern Jordan. Department of Natural Resources and the Environment, Jordan University of Science and Technology, 47(2): 145-152.

Machette, M.N., 1985. Calcic soils of the southwestern United States. In: D.L. Weide (Editor), Soils and Quaternary Geology of the southwestern United States, pp. 1-21.

Prothero D. R., Schwab, F., 2014. Sedimentary Geology: an introduction to sedimentary rocks and stratigraphy. W.H. Freeman, 3rd edition.

Retallack, G.J., 2001. Soils of the past: An introduction to paleopedology. Blackwell Science, Malden, MA, 404 pp.

Robins, C.R., Deurlington, A., Buck, B.J. and Brock-Hon, A.L., 2015. Micromorphology and formation of pedogenic ooids in calcic soils and petrocalcic horizons. Geoderma, 251-252: 10-23.

Schoeneberger, P. J., Wysocki, D. A., Benham, E. C., Soil Survery Staff., 2012. Field book for describing and sampling soils. National Resources Conservation Service, National Soil Survey Center, Version 3.0. 
Soil Survey Staff. 2019. Official Soil Series

Descriptions. USDA-NRCS http://soils.usda.gov/ technical/classification/ osd/index.html. Accessed 29 March 2019. 